\title{
Legal geography: an Australian perspective
}

Key words: legal geography, law, geography, materiality, relationality, Australia

\begin{abstract}
(230 words)
Law is a powerful influence on people and place. Law both creates and is created by the relationship between people and place, although it rarely acknowledges this. It frequently operates as if space doesn't matter. Law and legal processes, therefore, deserve greater attention from geographers. Legal geography is an emerging field of inquiry that facilitates much-needed attention to the inter-relationships between the environment, people and social institutions, including formal laws but also informal rules, norms and lore. Legal geographers seek to make the invisible visible: to bring the law into the frame of geography, and space and place into focus for the law. Both critical and applied in approach, legal geography offers descriptive, analytical and normative insight into economics, justice, property, power, geopolitics, governance and scale. As such it can enrich most areas of geographic inquiry as well as contribute to current policy debates about the regulation of space and place. Legal geography is a way for enlarged appreciations of relationality, materiality, multiscalarity and agency to be used to interrogate and reform the law. This introduction to a special 'themed paper' section of Geographical Research provides a window on legal geography scholarship, including its history, contribution and ambition. The papers in the collection explore issues grounded in the legal geographies paradigm, variously analysing matters empirically detailed while engaging in broader, theoretical debates and using both Australian and international case studies.
\end{abstract}




\section{Introduction}

The law is a major social institution, both generative of and responsive to people, place and spatial heterogeneity. Although legal systems are often predicated on the creation of spatial boundaries, including of jurisdictions and realty, the academic discipline of law possesses only very basic conceptions of geographic matters such as space, place and human-environment relations. It is often ignorant of geographic influences as well as its own geographic actions and effects. It tends to overlook spatial heterogeneity and the geographically grounded nature of its own processes. Both legal systems and the discipline of law therefore deserve geographers' attention as well as their contributions. Legal geography provides a way of addressing this gap. By interrogating the interactions between law, space and place, by questioning what the law is, and what it does, spatially, legal geography gives overdue attention to the inter-relationships between the environment, people and social institutions, including formal laws but also informal rules and lore as well as social custom and norms.

Historically, there has been insufficient attention paid by legal scholars to geography and by geographers to the law (see for e.g. Stratford, 1993). Although the law has always been a subject for geographers, it has seldom been identified as the central focus. It is also true that many geographers, especially political geographers, and others in cognate fields, for e.g. workers in critical political economy, political ecology, regulatory theory, legal anthropology and socio-legal studies (see for e.g. Amin, 2010; Moore, 1973; Harvey, 2001; Sassen, 2001; Strathern, 1999; Smith, 2001) will have been 'doing' legal geography without labelling it as such. There is a need to recognise this oversight and challenge scholars to give space, place and the environment, as well 
as the law, the recognition they each deserve. Place is used here to describe space to which meaning has been ascribed (e.g. Carter et al., 1993), acknowledging that space itself and other geographical entities such as scale are all equally social constructions, in part produced by institutions, including the law, and all do social and political work (see Smith, 2001, 18; and see also De Certeau, 2002, 74 for whom space is a practiced place). Environment means the Earth and our surroundings, but also refers to dynamic, emergent and non-binary appreciations of human-nature (and non- and more-than human) relationships. All of these facets of geography have representative force as well as performative and material life. Law and legal systems are similarly broad, including the performed (e.g. of the nation state, see Weber, 1998, or of property, see Blomley, 2013) as well as the representational and material products of rule-based systems intended to regulate human behavior (see for e.g. Anleu, 2000; Moore, 1973). Any study of the law also necessarily incorporates what is made illegal as well as legal, and sources of informal as well as formal control (see for e.g. Hall, 2012). Legal geography thus also considers what is placed both metaphorically and in reality beyond the bounds of the law, and challenges assumptions that have become naturalized and normalized (or routinized and sedimented, see discussion of Judith Butler's work in Nash, 2000). This includes assumptions about what is acceptable behavior, including questioning of what is considered within the discipline of law itself.

Importantly, legal geography includes what has traditionally lain beyond the scope of the discipline of law. Law is largely studied in the abstract, ignoring both its spatial and social context (see for e.g. Anleu, 2000; Moore, 1973; Posner, 1987). Legal geography addresses this 'legal closure', the solipsistic claim the law makes for its separateness 
and supremacy, in order to understand laws as embedded in (co-constituted) social and political life that is in turn emplaced (Blomley, 1994; Delaney, 2010). In demonstrating in particular that 'place matters' to law, legal geography addresses impoverished conceptions of space held by the law (Butler, 2009). Legal geography enacts a way for the heterogeneity, messiness, complexity, dynamism and emergent properties of people and place to challenge received orthodoxies of universality within law (PhilippopoulosMihalopoulos, 2011a). In recognizing the interconnection of law and space, legal geography also answers calls for the re-materializing of geography (Whatmore, 2006, 603). Without degenerating into (and noting the dangers of) parochialism, naturalistic fallacies and environmental determinism (Judkins et al., 2008; Rodman, 1992, Sluyter, 2003), and recognizing that reality itself is to varying degrees a construction (see for e.g. discussion in Haraway, 1992), places are co-creators of, as well as a proving ground, for law. While uneven effects and development arise from the interaction of social, political and legal processes these are also related to biophysical differences (Harvey, 2001). The materiality and particularity of heterogenous environments can also test and challenge universal and universalizing 'one size fits all' law (Barr and Devine-Wright, 2012; Faure et al., 2012), including through the resistance to regulation by regulated peoples (see for e.g. Bartel, 2013). Any rule invites subversion and, given the pluralistic exercise of power, conflict and resistance may also be generative and creative. The law cannot escape matter (except by denial) and any system incorporates the possibility of reflexivity via system interoperability (Philippopoulos-Mihalopoulos, 2011b, 53). 
Legal geography represents a shift to addressing the spatial in legal inquiry as well as a shift to addressing the law in geographical inquiry, in order to reform (and perhaps also transform) law, and make a practical difference in socio-economic and environmental jurisprudence. The dominant idea of law as abstract and aspatial, which has parallels in claims for justice to be blind, enables its agents to be complicit in the concealment of law's spatial effects and actions, with the task of lifting the veil largely left to (in terms of environmental law and politics) environmental, ecological and wild law scholars, political ecologists and political geographers (e.g. Blaikie and Brookfield, 1987; Tarlock, 2000; 2010), and, increasingly, in terms of laws, place and space more generally, legal geography. To borrow from Smith $(2001,15)$, aspatial treatments of law are necessarily one-dimensional and therefore depauperate. Ignorance of geography has political consequences (Smith, 2001, 17), for if we do not ask questions about the location of law's impact then its effects, including for example environmental destruction or the dispossession and genocide of Indigenous peoples, may be ignored. This also has implications for academic practice, particularly engaged scholarship and activism in legal arenas. Relevant here also are geographies of care and responsibility, ethics of care, research ethics (Gibson-Graham, 2003; Massey, 2004; Popke, 2009; McEwan and Goodman, 2010) and ultimately, normativity (Barnett, 2011) a project with which legal systems (admittedly prescriptive, and frequently also selectively moralistic) are most ostensibly engaged.

With this special 'themed paper' section of Geographical Research we hope to provide a window on what is still a relatively new world of geographical research and practice. There is a certain timeliness to this collection. A specialist Legal Geography Study 
Group of the Institute of Australian Geographers (IAG) was established in 2009. Dedicated panel sessions were held at IAG annual conferences in subsequent years and dedicated workshops in 2011 and 2013. Out of such activities has emerged the opportunity to collate here a number of representative papers. They explore issues grounded in the legal geographies paradigm, variously analyzing matters empirically detailed while engaging in broader, theoretical debates and using both Australian and international case studies.

\section{Legal geography: a brief background}

Legal geography encompasses many diverse areas of interest. These include prominent topics such as the regulation of self, space and of mobility, environmental issues, land use planning, property rights and major issues of power and socio-spatial justice. Legal geography is of necessity a multi-disciplinary, perhaps also inter-, trans- and postdisciplinary, pursuit (Braverman et al., 2013). To mirror Richie Howitt's $(2011,131)$ description of social geography, legal geography is therefore 'neither a unified subdiscipline nor a singular field of practice.' This quality in some ways reflects the breadth of geography and the pervasiveness of law, as well as the evolving and cyclic nature of academic inquiry and the relative youthfulness of legal geography as a subdiscipline.

While there were powerful antecedents, a special issue of Urban Geography (Blomley 1993), and Nick Blomley's Law, Space and the Geographies of Power (1994), heralded

a fresh engagement by geographers with the law, comprising an explicitly critical methodology and intent (Butler, 2009). Since then, there have appeared special issues of 
journals, numerous seminal papers, authored books and edited collections as well as seminars and conferences. It is not the intention to pull together an exhaustive list of key works here, or to select representative examples, however, we note that the literature has been punctuated by some important monographs, editorials and review papers (e.g. Blomley, 1993, 2005a, 2010a; Chouinard, 1994; Mitchell, 1998a, 1998b; Forest, 2000; Martin et al., 2010; Graham, 2011). Nick Blomley's co-edited book The Legal Geographies Reader (Blomley et al., 2001) gave the area greater visibility, especially in its critical vision. More descriptive and applied work includes Rudd $\mathrm{H}$. Platt's Land Use and Society: Geography, Law, and Public Policy (1996/2004). Of course, the boundaries between critical and applied approaches are fluid and Holder and Harrison's Law and Geography (2003) is an example of how wide-ranging the critical sphere can be. The individual perspectives of practitioners working within legal geography are also worth noting. With respect to planning, for example, Oren Yiftachel combines both theory and practice in his work, including The Power of Planning: Spaces of Control and Transformation (2001).

It is perhaps in the institution of property and the regulation of land use that law has its most obvious overlap with geography, and this is not an insignificant area in a settler society such as Australia. Whatmore (2002a, 211-212) highlights that critical legal geography can take us:

"beyond the "effects" of property rights on the balance of powers between preconstituted social subjects, revealing how they (re)configure the very mode of social agency and relationality and its territorialization in distinctive institutional 
forms - from the borders of nation-states and the compass of corporate markets to the calculus of the individual and the domain of the self.'

We can see such expressions of social agency and reconfigurations of law-space relations in numerous examples dealing with ownership of land and natural resources or rights over usage. To pick just one, Whatmore (2002a) critiques the High Court of Australia's decision in Mabo v Queensland (No 2) [1992] 175 CLR 1 ('Mabo') and its unsettling of the ideas of sovereignty, property and the 'native' in Australia (see also Graham, 2002; Langton et al., 2004). Nick Blomley's sustained engagement with property has drawn us to see property as having been based in an exclusionary, individualized privatization of land yet still offering hope for a diversity of meanings and other possible arrangements (e.g. Blomley 2003, 2004, 2005b, 2008a, 2008b, 2010b). Territory and citizenship are other rich areas and Stephen Herbert has forged strong working relations with local communities and police departments to examine policing in this context (Herbert, 1997, 2006). Many of these studies engage the sociolegal creation and enactment of what is inside and what is outside of the law. As Santos $(2002,85)$ notes, the legal field:

'is a constellation of different legalities (and illegalities) operating in local, national and global time-spaces.'

In the following discussion we consider the value of legal geography in relation to its constituent and other disciplines, and its engagement with wider academic debates. We map the reach of legal geographical inquiry and consider in particular the questions of what (and whose) space, and which (and whose) law. We close our discussion with a 
commentary on the particular value of an Australian legal geography before offering brief concluding remarks as to the contribution we wish to make.

\section{Discussion}

Geography needs to be made visible to the law, and the law needs to be revealed to geographers. It is this very invisibility that legal geography addresses. As Braverman $(2011,175)$ has observed, this is:

'the most crucial insight of Legal Geography: a "taken-for-grantedness" that physical and legal matters lend to each other. Indeed, more than any other "law and ..." pairing (e.g. law and economics, law and history, law and society etc.), the pairing of law and geography is about the hidden stuff that lies behind the physical or spatial site.'

It is the "taken for granted hidden stuff" that is the subject of legal geography.

\section{The contribution of legal geography}

Legal geography offers an important contribution to scholarship for two main reasons, in attending, first, to the geographical conditions, enablers and limits of law, for e.g. materiality and relationality; and second, to the geographical effects of law, for e.g. scale, geopolitics and (in)justice (Graham, 2011). Both foci invite critical questions about the sources, authority, functionality and viability of law. The analyses and conclusions of research employing the legal geography lens frequently challenge the extent and legitimacy of operation of certain kinds of laws, principally those of AngloEuropean origins, since underpinned by universalising and totalising goals yet with vested interests in class and property (hence also race and gender). In this way, legal 
geography may well be regarded as extending critical legal scholarship. Another significant feature of its approach is that it undermines the paradigm of anthropocentrism at the heart of modern Anglo-European law. Geography is one among many disciplines bringing concerted critique upon human-nature dualities (see for e.g. Bartel et al, forthcoming). Legal geography is one way for these initiatives to give effect to their purpose: supporting, through reformed interventions, an environment beyond economic exploitation, utilitarian benefit and humanist hubris. For this reason, legal geography also has important economic and cultural implications for contemporary research in human-nature relations. This is particularly so in the context of Australia's often-fraught environmental history (e.g. Flannery, 1994; Low, 1999; Lindenmayer, 2007; Weir, 2009). Working to see the interconnections between human, space and policy offers a way forward that can transcend debates that have become entrenched conflicts of interest (e.g. Bartel, 2013; Bartel et al., forthcoming).

The achievement of legal geography is thus not confined to illuminating various questions and insights into law. It also plays an important role in revealing the agency or actions and effects of law, as it comprises institutions, practices and things, in anthropogenic environmental change. In so doing, it makes possible different understandings on the relationship between the human and more-than-human (Whatmore, 2006) and permits revised and reflexive knowledges into different kinds of natural resource economies. The utility of legal geography is therefore not limited in its being culturally-specific, jurisdictionally-specific and geographically-specific. Indeed, anthropogenic environmental change is global in effect if not in origin, and thus legal geography is a helpful approach in examining the role of many kinds and forms of law 
and governance in facilitating, encouraging or prohibiting those changes and effects. Legal geography reveals what legal discourse rarely acknowledges - its material context. In this way, legal geography endeavours to re-connect the concealed, forgotten or prohibited connections between peoples and places, between the human and the more-than-human.

\section{Legal geography and materiality}

Legal geography research indicates the contingency of law on materiality despite the claims of various legal discourses that law is based on transcendental truth, universal economic necessity and enduring cultural origin (Graham, 2011). Around the world, the physical realm, as manifest in various and highly specific geological, hydrological, atmospheric and climatic conditions, determines the possibility and sustainability of laws and economies. Scholars of law and economics debate whether the law determines the operation of an economy or vice versa. Legal geographers, on the other hand, consider both law and economy as generative of and responsive to geographical contexts. Each is therefore geographically contingent and geographically performed and inscribed - sometimes in enduring and adverse ways. The often unarticulated but necessary fact about the relationship between law and geography is that it is mediated by the human economy of the given research subject. It is in the existence, security, ownership and distribution of the goods for life that law and geography frequently intersect. The effect of legal geography research on economic policy and scholarship is therefore an important, but under-acknowledged outcome of this work. 
For instance, legal geography implies the need for law reform where economies fail to understand and operate within biophysical limits. Frequently, the effects of laws based on the alienation of people and place are born of (and/or give rise to) economies that, being commodity-based, fail to perceive and accommodate the particularity of organisms and inter-dependent relationships within systems. Human knowledge of those systems is either set aside or forgotten and it is here that legal geography has potential to offer most - highlighting how practices are situated in space and law. Growth-based economies based on notionally fungible commodities that are grown in non-fungible conditions such as fertile soil, clean air, sunlight and water push to the limit their own viability and consequently the laws that facilitate and protect them. Legal geography requires the relationships between economies and environmental resources and outcomes to be revealed where they may otherwise be concealed, overlooked or forgotten even (or especially) while facilitating degradation and maladaptation. This is increasingly vital as we as a species attempt to respond to climate change, biodiversity loss, land and water degradation and other challenges of the Anthropocene, for which legal and notionally marketized (although legally underwritten) solutions are often implemented, regulatory and market failures frequently experienced, and therefore improved responses required (Craig, 2010; Crutzen and Stoermer, 2000; Crutzen 2002; Syvitski 2012). Much work remains to be done in regard to this aspect of legal geography, and while research on nature's commodification and marketization is key (Castree, 2004; Boydell et al., 2009), work on power (Allen, 2003) also proves useful, as demonstrated with the contribution from Williams in this issue. 


\section{Legal geography and the relational turn}

Geography more broadly has been influenced in the past by other disciplines (e.g. in the quantitative, social and cultural turns, see Smith, 2001 and also discussions by Browett, 1984; Hurst, 1980) and has also exerted its own impact, through the increased recognition of the importance of location, via the 'spatial turn' (Livingston, 2000; Warf and Arias, 2008). More recently, the influence of what is called here the 'relational turn', the recognition of co-constitutive human and non-human, has infused intellectual inquiry across the arts and sciences (Chakrabarty 2009; Davison, 2008; Latour, 1993; White, 2006; and see also with regards to thing theory, Brown, 2001 and actor network theory, Castree, 2002; Murdoch, 1997; 1998). Legal geography gives explicit recognition to this relationality, challenging earlier assumptions of space as inert and law as received (Butler, 2009). However, such beliefs continue to exert powerful sway, including in imagining legal systems as autopoetic, i.e. distinct, disconnected and operating according to internal laws and rhythms in isolation from all else. The selfstyled solipsism of law has perhaps most effectively been eroded by those seeking to assess its efficacy (and to address its failures) through an understanding of its interactions with the social (Moore, 1973). Increasingly also it is through the biophysical realities of locales that the law is identified as having co-constitutive people-and-place ingredients.

Disconnections, including the transplantation of Anglo-European law to Australia, cause disjuncture and instability, but may also, through resistance and obstruction, lead to creation and transformation. In this way the law may be said to be (to a certain degree) adaptive to new and changing conditions. However, the law may also be 
preferentially connected to, and therefore perpetuate, certain values over others. The law has the power to make the world in its own image, not always consciously and with often unknown effects. Some values, like memes (or self-fulfilling prophesies) may ensure that they retain their preeminence, for example the values of certainty, predictability and universality in law, which inscribe and proscribe its totality. These generalising and normalising forces of law can render injustice, whether through applying categorisations of difference upon which exclusionary practices are exerted, such as othering and boundary (and border)-making, or ignoring difference (for e.g. the heterogeneity of environments or people) and providing for (apparently) fair treatment but in reality causing egregiously unfair (and perverse) outcomes (e.g. Havemann, 2005; Jackson, 2006; Sherval, 2009; Porter, 2010).

Legal systems also have an emancipatory as well as oppressive potential for the 'subjects' that they seek to regulate, be they human or non-human. Howitt and Jackson (1998) highlight many of the historical and contemporary roles that geography and geographers have played in reconfiguring colonial regulations over Aboriginal and Torres Strait Islander Australians. There is a significant opportunity for legal geography to contribute to a decolonisation of language, policy, law and professional practice (e.g. in planning and natural resource management). There is also a potential to explore the role of Indigenous customary laws and protocols that have long been ignored or overridden by state law, but are receiving renewed attention through international actions such as the UN Declaration on the Rights of Indigenous Peoples (UNDRIP) and the Nagoya Protocol to the Convention on Biological Diversity (e.g. Bavikatte and Robinson, 2011) with subsequent responses by communities and governments. Indeed, 
the way powerful or marginalized actors influence decisions and laws variously from the local to global, embeds understandings in a multiscalar regulatory context (e.g. Howitt, 1993; Whatmore, 2002b, 90-116; Williams, 2010).

\section{Legal geography and scale}

In opening a conversation about the nuanced connections between law and geography it is important to recognise that legal systems do not exist at just one level of construction and enforcement, especially in a federal nation-state like Australia. Rather, legal systems are multiscalar, with - in Australia, at least - an overlapping of national, state, local and occasionally also regional jurisdictions, which in turn interact with systems of customary (Indigenous) decision-making, informal rules (or social and cultural norms) as well as international conventions. Despite attempts to separate legal powers across these scales, this is never complete, generating an ongoing conflict of laws across and between scalar frames (Weller, 2007). The legalities and illegalities produced by legislation and regulation at each scale do not neatly align, and therefore interact to produce a complex mosaic of legal (and illegal) geographies at different scales (Santos, 1995; Howitt, 2003; Valverde, 2009; De Souza Mello Bicalho and Hoefle, 2010). There is increasing interest being focused on the role that these converging legal horizons play in the constitution of places and subjectivity. For example, recent research has shown the significance of the local scale of 'citizenship constitution', which demonstrates the complex multiscalarity of legal-regulatory processes that converge upon subjects and fabricate their status as sexual citizens (Grundy and Smith, 2005). Furthermore, there is often tension between the regulation of places and subjectivities at different intranational and inter-national scales, leading to multiscalar conflicts. What is unlawful at 
one scale, for example, may be challenged by legislation at another scale, or established social norms at another scale, and this can generate imbrication and disjuncture between legal geographies at different overlapping scales.

A politics of law and scale emerges when actors have the ability to enrol others to agreement at jurisdictionally different scales (e.g. enrolling national-level bureaucrats to a global treaty or convention). This is then often resisted by competing or alternate social and political forces. For example, we regularly see US trade negotiators forumshift and scale-shift between agendas under multilateral ('global') agreements in the World Trade Organization (WTO), to seeking regional agreements and bilateral (stateto-state) agreements in order to secure economic preferences. As Santos $(2002,85)$ explains, the way law's potential evolves:

'whether towards [oppressive] regulation or emancipation, has nothing to do with the autonomy or self-reflexivity of the law, but rather with the political mobilisation of competing social forces.'

Another example from international trade law to this end, is the combination of both coercive (e.g. trade sanctions and 'tied-aid') and non-coercive approaches (e.g. education and 'technical assistance') by countries like the US or by the EU to ensure trade partners comply with their governmental objectives for harmonized trade laws (Robinson and Gibson, 2011). Further research is required to account for the multiscalarity of legal-regulatory processes, and the complexities and contestations that result (Gorman-Murray, 2011). 
Finally, in considering how these multiscalar local, state, national, and transnational rules converge on diverse subjects and places, research has begun to draw attention to the many mechanisms - policing, planning, education, licensing - through which subjectivity and place is moulded through the law, as discussed in the paper by Prior et al. in this issue. It is through the complex assemblage of these diverse mechanisms that the regulation of subjectivity and place by authorities becomes capable of deployment. For example, Ford $(2001,209)$ notes that:

'Territorial jurisdiction functions to produce ... citizen-subjects by encouraging people to behave and to think of themselves in particular ways and discouraging other modes of behaviour and self-knowledge.'

These mechanisms enact assorted attempts at the calculated administration of diverse aspects of subjectivity and place, through countless often-competing tactics of persuasion, management, education, placement and encouragement. One of the most obvious mechanisms for regulating subjectivity has been direct, coercive, physical control exercised on the body through criminal law as applied by the police. Other scholarship, such as Prior and Crofts (2011), has identified the operation of more diffuse mechanisms for regulatory contro1, such as planning, which operates through the control of the space in which particular subjectivities take place, by reference to such issues as community public health and amenity standards. We need greater interrogation of not only the multiscalarity and multiplicity of local, state, national and transnational laws that converge on diverse subjects and places, but also of the diverse mechanisms through which those rules are deployed (Prior, 2008; Prior et al., 2012).

Power and place: geopolitical insights of legal geography 
The role of legal geography is at all times contingent upon our understandings of space and what occurs in relation to that space. Law may be ever-present through either representational systems or as exercised power, yet it is often only in relation to the social or political places that are produced, maintained or transformed that we recognise its dynamism (Delaney et al., 2001). This is particularly apparent when we consider its often contentious role in geopolitics under which places, regions and territory are continually defined and redefined by issues of sovereignty and authority (local and external) and where decisions about inclusion and exclusion are constantly being made and remade.

Contemporary geopolitics identifies the sources, practices and representations that allow for the control of territory and the extraction of resources (Flint, 2011), thus the role/rule of law and the legal meanings associated with it are present not only in the formation of the nation-state itself but also in its ongoing operation. Historically, through the legalisation of power - material and discursive, and the boundaries of space, nation-states and their authority were in general, adequately contained and sustained. With the advent of supranational institutions such as the UN, World Bank, IMF and the WTO and through processes such as globalisation and mobilisation, local and national authority is now able to be challenged by external agents and their growing demands. Sometimes these demands take the form of calls for more access to land and resources (usually by foreign MNCs), sometimes they are appeals for greater internal reform and governance, including for measures for the protection of Indigenous people's rights and livelihoods, which if ignored, can lead to the rise of global resistance movements. Therefore, the legal is decidedly ever-present in all these types of demands and more 
generally in the ongoing geopolitical concerns of nation-states, specifically those of maintaining order and security.

Legal geography in respect to geopolitics today then, is very much about what Allen $(2003,2)$ refers to as a 'relational sense of power', where actors and actions are shaped by socio-political aspects that are both historically and culturally situated. Having a geographical understanding of how the law is utilised and applied in different settings allows not only for greater scrutiny of its impacts on the ground; it also helps in teasing out the tensions that exist between law and geography as disciplines. A greater appreciation of the dynamics of each, also allows for further acknowledgment of, for example, the fact that across the world today in Africa, Latin America, China and in Australia, issues such as 'land reform' actually mean 'land law reform' (Jones, 2003, 4). Whilst ever these types of reforms and others like them continue at any scale, for whatever purposes - from the promotion of resources, markets, and productivity, to enhancing equality of asset holding, or the formalisation of customary tenures, there will always be an important place for legal geography in interpreting these processes and in recognising the often counterintuitive consequences that occur as a result of such reforms and their attempts to control space (Jones, 2003).

\section{Legal pluralism and governance}

Legal geography is not just about bringing a geographical perspective to formal legal systems alone. Formal law and its institutions are just one aspect of the rule-based architecture that structures and governs society. So-called 'formal' laws interact with informal customs and lore, social conventions and norms, religion and dogma, as well 
as the economy. These interactions form the subject of much study in the areas of policy evaluation - for example of legal efficacy, efficiency and equity - as well as in regulatory theory. Formal law may derive much of its (often silent) ideology and values from pre-existing systems of lore and norms, and development and implementation are also affected by current convention. All systems are subject to change and the evolution of law, lore and norms are not necessarily conjoined. One obvious connection however can be made through the creation and legitimation of legal jurisdictions by the state essentially temporal and spatial scales of regulation. Following common law recognition of native title in the historic Mabo decision, Australian geographers have examined the articulation between Indigenous laws and modernist statutory laws and many are exploring ways in which contemporary environmental management institutions and practices can embrace co-existing property regimes (Agius et al, 2007; Davies, 2003; Gillespie, 2011; Jackson and Langton, 2012; Palmer, 2007; Porter, 2010). However the relationship is not unproblematic, as the hierarchical power exerted by Anglo-European legal systems is everywhere evident, including in the Mabo decision itself and in subsequent native title legislation (Kelly and Bradfield, 2012). Australia has also been criticized for its failure to discharge International treaty obligations with regards to the rights of Indigenous peoples (Strelein et al., 2001). At the same time the international sphere we see customary laws and associated norms regarding Indigenous or 'traditional' knowledge breached through use of such knowledge towards new 'inventions' or discoveries, as legitimised by international patent and intellectual property law, as discussed in the paper by Robinson in this issue. 
Formal law may lead social change, and it is often used as a powerful tool for engineering change, however, without broader social agreement (or significant force, undermining at once considerations of justice and legitimacy) conflict, and regulatory failure may ensue. For example, where formal laws and processes conflict with the economy (e.g. Yeager, 1991) or with social norms (e.g. Bartel and Barclay, 2011; Gillespie, 2011) the limitations of law and the importance of scale, context, and contingency are very evident. Here a geographic perspective is useful for advancing the interrogation of legal pluralism (for an overview of contested meanings of legal pluralism, see Merry, 1998; Berman, 2009) and site-specific factors that may variously enable, constrain and explain disparate outcomes within and between jurisdictions and locations. Such factors may be related to social and/or environmental differences and place particulars (traditionally the geographer's stock-in-trade) and a geographical understanding can contribute insights with explanatory power that the discipline of law may be unlikely to achieve on its own. For example, formal laws are imposed uniformly over jurisdictions that may vary widely in biophysical and socio-cultural measures. Such heterogeneity presents a challenge for generalised and abstract laws. Gillespie's work in examining World Heritage regulation at Angkor, illustrates the point that internationally-inspired heritage regulations can compromise the overarching objectives. Gillespie argues that a failure to both (1) recognize and (2) value multiple legal systems and norms may undermine overarching cultural and natural heritage protective regimes (Gillespie, 2011). Laws must accurately represent conditions 'onthe-ground' or otherwise fail the 'reality tests' of implementation: one-size may not fit all. However, if laws are too reflexive or particular, then they may sacrifice the expectation that law is certain and uniformly pertaining to all in society. 
Just as a geographic perspective is useful for examining the complexity of multiple legal mechanisms, it is also essential for appreciating the diversity of legal and regulatory actors, and the distributed power between non-human as well as human agents, including that of places themselves (Norton, 2000; Wright et al., 2012). The term governance is currently used to encompass the range of non-institutional actors that interact with formal laws as well as generating their own governing influences (Alexander, 2006). Collaborative governance is recommended for the treatment of regulatory failures, and not just for liberal democratic ideals and social justice objectives, but also to recognize, particularly in environmental law, the critical importance of place-based understandings, including local and vernacular knowledge (Bartel, 2013; Broderick, 2005; Faure et al, 2012; Fischer, 2000; Gruber, 2010; Gunningham, 2009; Johnson et al., 2007; Wainwright et al, 2000; Weber, 2000).

Regionalization of governance to the ecosystem, bioregion and catchment levels is also being adopted (including in multi-jurisdictional contexts, for e.g. in Regional Forest Agreements and the Murray Darling Basin in Australia) although not without significant challenges (Farrelly, 2005; Lane, 1999; Lane et al, 2004; Lloyd et al, 2005; Macleod and Goodwin, 1999; Martin and Becker, 2011). There is also a role here for nested and polycentric governance to connect scales, as environmental issues both fall and are needed to be addressed at all levels from the local to the global and market and regulatory failures continue to perpetuate destruction (Jessop, 1998; Marshall, 1998; Ostrom, 1995; 2005). Many environmental issues currently addressed and re-made and scaled by environmental laws at the global level simply extend the reach of state legal 
institutions as well as dominant capitalist practices and processes of commodification. For example, carbon markets such as those promoted by UN REDD+ regimes entail risks and challenges for governance that appear to be overlooked by current approaches (Martin, 2013). These regimes will not only have differential effects locally but also arguably maintain processes of dispossession and commodification that inherently perpetuates exploitation rather than environmental protection and equity (see for e.g. Amin, 2010; Bartel et al., forthcoming; Harvey, 2001; Wallerstein, 2011; Wainwright et al., 2000; Webber, 1994). At the same time environmental and carbon markets and their associated regulatory architectures may offer creative and emancipatory opportunities for peoples and places (see for e.g. Gerrard, 2008). There is however continuing economic pressure to weaken existing legislative environmental protections in several countries, including Australia (see for e.g. Conacher, 1980; Driessen, 2003; Mercer and Marden, 2006). This diminishment has been recognised to have grown into such a significant problem that a principle of non-regression (see Prieur, 2012) has been adopted by the European Parliament (Resolution of European Parliament, adopted 29/9/2011, para. 97, and see also the IUCN World Conservation Congress Resolution on the 'Need for non-regression in environmental law and policy' WCC-2012-RES128-EN).

Australian legal geography: unique and universal truths

A final word needs to be made about what may be the unique contribution, if any, of Australian legal geography. If we take as read that place is important, then what is important about legal geography emanating from this nation? To answer this question various suggestions might be put, including that it is a large island nation, situated at a 
distance from many other nations (inflicting its so-called tyranny), therefore providing 'outsider' or observer perspective (Wilson, 1956). It could be that this distance facilitates greater skepticism of ideas from other locales, and particularly perhaps a critical approach to legal systems imposed from elsewhere, especially in the context of colonisation. Perhaps this is further supported by democratic political and multicultural social conditions. There is, of course, also the biophysical landscape, possessing a wide variety of environmental facets and challenges. It is this combination of factors that perhaps focuses our interest on the matters of place and materiality, of power and context, which can generate productive critique at the intersection(s) of law and geography. If Australian legal geography aims to provide a more careful articulation of the (seemingly) universal word of law with the locally contingent differentiation of the world, then it also needs to embrace a relationality that is explicitly material too. An initial key point is that law as a paradigm or culture is based in reason and hence its practice has long valorised abstraction. Indeed, this form of law has permitted its easy movement around the world, for example, in seeing Blackstone reborn in the colonies of New Holland. But then, as we've already indicated above, its application can become problematic as the new context of, in this case, the Australian antipodes, presents challenges as well as opportunities in which law is implicated. Consider, similarly, Whatmore's (2003) description of the colonisation of Australia as a collision of worlds and legal systems such that British law obliterated (to whatever degree and however temporarily) Indigenous practices including those of sovereignty and land rights. In more recent times we encounter the growing realisation that Australian environmental governance is deficient, and illegitimate, without the input of Aboriginal and Torres Strait Islander peoples (McNamara and Westoby, 2011; Ayre and McKenzie, 2012). 
The very stuff of the world grounds law, and so we have noted that the physical environment, and the plenitude of things (human and non-human) with which it is filled, provides the basis and source for law. In order to better understand our being in the world, and thus our being imbricated in its legal geographies, we need to look more closely at and engage further with the material substance and affective relationships encountered and experienced therein. We have emphasised too that there is some twoway traffic or recursive interaction occurring here: the material world in all its difference and contingency shapes how law is conceived and especially then interpreted and delivered, but the law likewise has a critical role in constituting that world. A greater appreciation of the reflexivity that can inhere in this making of the world in and through law is valuable. The emerging significance of the legal relations surrounding Indigenous artefacts and their recognition, repatriation and restitution is one relevant exemplar. Likewise, there is the enrichment of Anglo-European law with Indigenous law in Australia.

Our lived practices and relationships with and among material things are enabled or constrained in situ not least through law. Its practice might then be more enduring and/or effective if alert to its particular emergence in place and through relationships with things. Of course, a call to attend more to the material things of the world has already been made by legal geographers in the northern hemisphere (Blomley, 2007; Delaney 2001, 2003; Whatmore, 2003). We would further urge, however, that beyond noting the important presence of such things as a legal document, a judge's gavel, prison walls or set of handcuffs, we acknowledge their power, agency or action in the 
world. In this sense, we follow developments in ontological thought availed by feminists, social constructivists and others such as actor-network theorists and nonrepresentational theorists for whom many different worlds are assembled variously of humans and things thus giving some form of existence and capacity to each other.

In the realisation or performance of these worlds, including ours of Australian legal geographies, there are social, political and economic as well as legal relationships that are intertwined in what are their equally material instantiations. Marx's interest in the nature of things (and the things of nature) as fetishised commodities to be owned, exchanged and used, is a case in point. However, this is still probably no more evident than in terms of the material things that continue to get caught up in the law through their particular relationships including, most notably, that of alienation under capitalism

and hence as the objects of property rights. Indigenous dispossession, described famously by the anthropologist W.E.H. Stanner (1968/2009, 182ff), as the 'great Australian silence', is one aspect of the Australian condition generative of both unique and generalizable legal geography.

\section{Concluding remarks}

Although legal geography lends itself well to a range of research subjects across the world, its greatest impact is where its focus reveals the importance of scale, time and connection in specific local contexts. Attending to material conditions, limits and connections, legal geography is necessarily also attentive to contexts of time, historic and predictive as well as contingent. For example, although the histories of many lands 
and nations colonised by Anglo-Europeans in the seventeenth century share important political histories, they also have, in geographical terms, very different material histories. In other words, legal geography research that explores relationships between the development and operation of both Indigenous and non-Indigenous laws and environmental changes is necessarily able to reveal what is distinctive about those developments and operations. Research on the topic of property laws and their environmental consequences in Australia, for example, yields different results and conclusions to similar work elsewhere. The ultimate achievement of legal geography, then, is to indicate and advocate the fundamental importance of connecting law and geography for the sustainability of both, not as separate taxonomic categories but as parts of integrated systems. That law does not transcend place but is dependent on it is not a truth generally acknowledged by law's servants and scholars. By situating law in space, that is, within its physical conditions and limits, legal geography encourages place-based knowledge to form law's basis. We are advocating for a paradigmatic shift, from the alienation of people and place in law and geography to their necessary connection. In this way legal geography provides both intellectual insight and realworld application: it can produce work of practical policy relevance as well as speak truth to power. Serving this function, legal geography is part of 'the means and responsibility' of legal scholars and geographers to collaboratively 'find solutions' (Head, 2011, 77).

\section{Acknowledgements}


This paper and the papers appearing in this special themed section arose out of a dedicated writer's workshop held at the University of New England in 2013. The authors would like to thank the Institute of Australian Geographers for funding this workshop, and for supporting the Legal Geography Study Group since its inception in 2009. Thanks to the members of the Study Group, its office bearers, the workshop participants, and additional thanks to Robert Gale, Jo Gillespie and Maria Cotter for comments on an earlier draft. Thanks to the reviewers and editorial team.

\section{References}

Agius, P., Jenkin, T., Jarvis, S., Howitt, R. and Williams, R., 2007: (Re)asserting Indigenous Rights and Jurisdictions within a Politics of Place: Transformative Nature of Native Title Negotiations in South Australia. Geographical Research 45(2):194-202.

Alexander, E. R., 2006: Institutional design for sustainable development. Town Planning Review 77 (1), $1-27$.

Allen, J., 2003: Lost Geographies of Power. Blackwell, Oxford.

Amin, S., 2010: Exiting the Crisis of Capitalism or Capitalism in Crisis? Globalizations 7,1-2, 261-273.

Anleu, S. L. R., 2000: Law and Social Change. Sage, London.

Barnett, C., 2011: Geography and ethics: Placing life in the space of reasons. Progress in Human Geography 36(3), 379-388.

Barr, S. and Devine-Wright, P., 2012: Resilient communities: sustainabilities in transition. Local Environment: The International Journal of Justice and Sustainability 17(5), 525532.

Bartel, R., 2013: Vernacular knowledge and environmental law: cause and cure for regulatory failure, Local Environment: The International Journal of Justice and Sustainability, DOI: $10.1080 / 13549839.2013 .798636$ 
Bartel, R. and Barclay, E., 2011: Motivational postures and compliance with environmental law in Australian agriculture. Journal of Rural Studies 27, 153 - 170.

Bartel, R., McFarland, P. and Hearfield, C., Forthcoming: Taking a De-Binarized Envirosocial Approach to Reconciling the Environment vs Economy Debate: Lessons from Climate Change Litigation for Planning in NSW, Australia. Town Planning Review.

Bavikatte, K. and Robinson, D. F., 2011: Towards a People's History of the Law: Biocultural Jurisprudence and the Nagoya Protocol on Access and Benefit Sharing. Law, Environment and Development Journal 7(1): 35 - 55.

Berman, P.S., 2009: The New Legal Pluralism. Annual Review of Law and Social Science 5: 225-242.

Blaikie, P. and Brookfield, H., 1987: Land Degradation and Society, Methuen, London.

Blomley, N., 1993: Editorial: Making space for law. Urban Geography 14(1), 3-6.

Blomley, N., 1994: Law, Space and the Geographies of Power. The Guilford Press, New York and London.

Blomley, N., 2003: Law, property and the geography of violence: the frontier, the survey and the grid. Annals of the Association of American Geographers 93(1), 121-141.

Blomley, N., 2004: Unsettling the City: Urban land and the politics of property. Routledge, New York and London.

Blomley, N., 2005a: Remember property? Progress in Human Geography 29(2), 125-127.

Blomley, N., 2005b: Flowers in the bathtub: boundary crossings at the public-private divide. Geoforum 36: 281-296.

Blomley, N., 2007: Making private property: enclosure, common right and the work of hedges. Rural History 18(1), 1-21.

Blomley, N., 2008a: Enclosure, common right and the property of the poor. Social and Legal Studies 17(3), 311-331.

Blomley, N., 2008b: Simplification is complicated: property, nature, and the rivers of law. Environment and Planning A 40, 1825-1842. 
Blomley, N., 2010a: Property, liberty, and the category. Geoforum 41, 353-355.

Blomley, N., 2010b: Cuts, flows, and the geographies of property. Law, Culture and the Humanities 7(2), 203-216.

Blomley, N., 2013: Performing Property: Making The World. The Canadian Journal of Law \& Jurisprudence 26(1), 23-48.

Blomley, N., Delaney, D. and Ford, R., (eds) 2001: The Legal Geographies Reader: Law, Power, and Space. Blackwell, Oxford.

Boydell, S., Sheehan, J.B. and Prior, J.H., 2009: Carbon property rights in context, Environmental Practice 11(2), 105-114

Braverman, I., 2011: Hidden in Plain View: Legal Geography from a Visual Perspective. Law, Culture and the Humanities 7(2), 173-186.

Braverman, I., Blomley, N., Delaney, D. and Kedar, A., 2013: The Expanding Spaces of Law: A Timely Legal Geography, Stanford University Press, Forthcoming. SUNY Buffalo Legal Studies Research Paper No. 2013-032.

Broderick, K., 2005: Communities in Catchments: Implications for Natural Resource Management. Geographical Research 43(3), 286-29.

Butler, C., 2009: Critical legal studies and the politics of space. Social and Legal Studies 18(3), 313-332.

Carter, E., Donald, J. and Squires, J., 1993: Introduction. In Carter, E., Donald, J. and Squires, J. (eds) Space and Place: Theories of Identity and Location, Lawrence and Wishart, London.

Castree, N. 2002: False Antitheses? Marxism, Nature and Actor-Networks, Antipode 34(1), $111-146$.

Castree, N., 2004: The geographical lies of commodities: problems of analysis and critique. Social and Cultural Geography 5(1), 21-35.

Chakrabarty, D., 2009: The climate of history: four theses. Critical Inquiry 35 (Winter), 197222. 
Chouinard, V., 1994: Geography, law and legal struggles: which ways ahead? Progress in Human Geography 18, 415-440.

Conacher, A., 1980: Environmental legislation in Western Australia. Australian Geographical Studies 18(1): 51-61.

Craig, R. K., 2010: 'Stationarity is Dead' - Long Live Transformation: Five Principles for Climate Change Adaptation Law. Harvard Environmental Law Review, 43(1), 9-75.

Crutzen, P.J., 2002: The geology of mankind. Nature 415 (6867), 23.

Crutzen, P.J. and Stoermer, E.F., 2000: The Anthropocene. IGBP Newsletter 41 (17), 17-18.

Davies, J., 2003: Contemporary Geographies of Indigenous Rights and Interests in Rural Australia. Australian Geographer 34(1), 19-45.

Davison, A., 2008: The trouble with nature: ambivalence in the lives of urban Australian environmentalists. Geoforum 39 (3), 1284-1295.

De Certeau, M., 2002: Spatial Stories. In Ballantyne, A. (ed) What is Architecture? Routledge, London. $72-87$.

Delaney, D., 2001: Making nature/marking humans: law as a site of (cultural) production. Annals of the Association of American Geographers 91(3), 487-503.

Delaney, D., 2003: Beyond the word: law as a thing of this world. In Holder, J. and Harrison, C. (eds) Law and Geography. Oxford University Press, Oxford, 67-83.

Delaney, D., Ford, R.T., and Blomley, N., 2001: Preface: Where is the Law? In Blomley, N., Delaney. D. and Ford, R.T. (eds) The Legal Geographies Reader: Law, Power, and Space. Blackwell, Oxford, xiii-xxiv.

De Souza Mello Bicalho, A.M., and Hoefle, S.W. 2010: Economic Development, Social Identity and Community Empowerment in the Central and Western Amazon. Geographical Research 48(3), 281-296.

Driessen, D. M., 2003: The Economic Dynamics of Environmental Law. MIT Press, Cambridge, USA. 
Farrelly, M., 2005: Regionalisation of Environmental Management: a Case Study of the Natural Heritage Trust, South Australia. Geographical Research 43(4), 393-405.

Faure, M., Goodwin, M., and Weber, F., 2010: Bucking the Kuznets curve. Virginia Journal of Environmental Law 51 (1), 95-156.

Fischer, F., 2000: Citizens, experts and the environment: local knowledge. Duke University Press, Durham.

Flannery, T., 1994: The Future Eaters. Reed Books, Sydney.

Flint, C., 2011: Introduction to Geopolitics. Routledge, Oxford.

Ford, R. T., 2001: Law's territory (a history of jurisdiction). In Blomley, N., Delaney. D. and Ford, R.T. (eds) The Legal Geographies Reader: Law, Power and Space. Blackwell, Oxford, 200-217.

Forest, B. 2000: Placing the law in geography. Historical Geography 28(1), 5-12.

Gerrard, E., 2008: Impacts and opportunities of climate change: Indigenous participation in environmental markets. Land, Rights, Law: Issues of Native Title 3(Issue Paper No. 13), $1-14$.

Gibson-Graham, J.K., 2003: An ethics of the local. Rethinking Marxism 15 (1), 49-74.

Gillespie, J., 2011: Legal Pluralism and World Heritage Management at Angkor, Cambodia. Asia Pacific Journal of Environmental Law 14(1\&2), 1 - 19.

Graham, N., 2002: Ec-centric places: Departures in Australian Property Law. In Pons, X. (ed), Departures: how Australian reinvents itself, Melbourne, Melbourne University Press, 245-257.

Graham, N., 2011: Lawscape. Routledge, New York and London.

Gorman-Murray, A., 2011: Queerying planning in Australia: The problems and possibilities of multiscalar governance for LGBT sexual minorities. In Doan, P. (eds), Queerying 
Planning: Challenging heteronormative assumptions and reframing planning practice. New York, Ashgate Publishing Ltd, 129-143.

Gruber, J.S., 2010: Key Principles of Community-Based Natural Resource Management: A Synthesis and Interpretation of Identified Effective Approaches for Managing the Commons. Environmental Management 45:52-66.

Grundy, J. and Smith, M., 2005: The politics of multiscalar citizenship: the case of lesbian and gay organizing in Canada. Citizenship Studies 9(4), 389-404.

Gunningham, N., 2009: The new collaborative environmental governance: the localization of regulation. Journal of Law and Policy 36, 145-166.

Hall, T., 2013: Geographies of the illicit: globalization and organized crime, Progress in Human Geography 37(3), 366-385.

Haraway, D., 1992. The Promises of Monsters: A Regenerative Politics for Inappropriate/d Others. In Grossberg, L., Nelson, C. and Treichler, P. A. (eds) Cultural Studies Routledge, New York, 295-337.

Harvey, D., 2001: Globalization and the Spatial Fix. Geographische Revue 2, 23-30.

Havemann, P., 2005: Denial, Modernity and Exclusion: Indigenous Placelessness in Australia. Macquarie Law Journal 5, 57-80.

Head, L., 2011: More than human, more than nature: plunging into the river. Griffith Review 31, 74-82.

Herbert, S., 1997: Policing Space: Territoriality and the Los Angeles police department. University of Minnesota Press, Minneapolis.

Herbert, S., 2006: Citizens, Cops, and Power: Recognizing the Limits of Community. University of Chicago Press, Chicago.

Holder, J. and Harrison, C. (eds). 2003: Law and Geography. Oxford University Press, Oxford.

Howitt, R., 1993: "A world in a grain of sand": towards a reconceptualisation of geographical scale. Australian Geographer 24(1), 33-44. 
Howitt, R., 2003: Scale. In Agnew, J., Mitchell, K. and Toal, G. (eds) A Companion to Political Geography. Blackwell, Oxford, 138-157.

Howitt, R., 2011: Knowing/doing. In Del Casino, V.J., Thomas, M.E., Cloke, P. and Panelli, R. (eds) A Companion to Social Geography. Wiley-Blackwell, Oxford, 131-145.

Howitt, R. and Jackson, S., 1998: Some things do change: Indigenous rights, geographers and geography in Australia. Australian Geographer 29(2), 155-173.

Hurst, M. E. E., 1980: Geography, social science and society: towards a de-definition. Australian Geographical Studies 18(1), 3-21.

Jackson, S., 2006: Compartmentalising culture: the articulation and consideration of Indigenous values in water resource management, Australian Geographer 37(1), 19-32.

Jackson, S. and Langton, M., 2012: Trends in the recognition of indigenous water needs in Australian water reform: the limitations of 'cultural' entitlements in achieving water equity. Journal of Water Law 22(2/3), 109-123.

Jessop, B., 1998: The Rise of Governance and the Risks of Failure: the Case of Economic Development. International Social Science Journal, 50 (155), 29-45.

Jones, G.A., 2003: Camels, chameleons, and coyotes: problematizing the 'histories' of land law reform. In Holder, J. and Harrison, C. (eds) Law and Geography, Oxford University Press, Oxford, 169-190.

Johnson, J. T., Cant, G., Howitt, R. and Peters, E., 2007: Creating Anti-colonial Geographies: Embracing Indigenous Peoples' Knowledges and Rights. Geographical Research 45(2), $117-120$.

Judkins, G., Smith, M., and Keys, E., 2008: Determinism within human-environment research and the rediscovery of environmental causation. The Geographical Journal 174 (1), 1729.

Kelly, G. and Bradfield, S., 2012: Winning Native Title or winning out of native title? The Noongar Native Title Settlement. Indigenous Law Bulletin 8(2), 14-16. 
Lane, M. B., 1999: Regional Forest Agreements: Resolving Resource Conflicts or Managing Resource Politics? Australian Geographical Studies 37(2), 142-153.

Lane, M. B., McDonald, G. T. and Morrison, T. H. 2004: Decentralisation and Environmental Management in Australia: a Comment on the Prescriptions of The Wentworth Group, Australian Geographical Studies 42(1), 103-115.

Langton, M., Tehan, M. and Palmer, L. 2004: Introduction. In Langton, M., Tehan, M., Palmer, L and Shain, K. (eds) Honour Among Nations? Treaties and Agreements with Indigenous People. Melbourne University Press, Melbourne, 1-26.

Latour, B., 1993: We have never been modern. Harvester Wheatsheaf, London.

Lindenmayer, D. B., 2007: On borrowed time: Australia's environmental crisis and what we need to do about it. Penguin Books, Camberwell.

Lloyd, D., Van Nimwegen, P. and Boyd, W.E. 2005: Letting Indigenous People Talk About Their Country: a Case Study of Cross-Cultural (Mis)communication in an Environmental Management Planning Process. Geographical Research 43(4), 406-416.

Livingston, D. N., 2000: Putting Geography in its Place. Australian Geographical Studies 38(1), $1-9$.

Low, T., 1999: Feral Future. Viking, Camberwell.

MacLeod, G. and Goodwin, M., 1999: Space, scale and state strategy: rethinking urban and regional governance. Progress in Human Geography 23(4), 503-527.

Marshall, G. R., 2008: Nesting, subsidiarity, and community-based environmental governance beyond the local level. International Journal of the Commons 2(1), 75-97.

Martin, P. V., 2013: The risks of using REDD+ to manage rich socio-ecological systems. International Journal of Rural Law and Policy Special Edition, 1-13.

Martin, P. and Becker, J. 2011: A Tale of Two Systems: Conflict, Law and the Development of Water Allocation in Two Common Law Jurisdictions. International Journal of Rural Law and Policy Special Edition, 1-19. 
Martin, D.G., Sherr, A.W. and City, C., 2010: Making law, making place: lawyers and the production of space. Progress in Human Geography 34(2), 175-192.

McEwan, C. and Goodman, M. K., 2010: Place Geography and the Ethics of Care: Introductory Remarks on the Geographies of Ethics, Responsibility and Care. Ethics, Place \& Environment A Journal of Philosophy \& Geography, 13(2), 103-112.

Mercer, D. and Marden, P., 2006: Ecologically Sustainable Development in a 'Quarry' Economy: One Step Forward, Two Steps Back. Geographical Research 44(2), 183-203.

Merry, S.E., 1998: Legal pluralism. Law \& Society Review, 22(5), 869-896.

Mitchell, D., 1998a: Anti-homeless laws and public space I. Begging and the First Amendment. Urban Geography 19(1), 6-11.

Mitchell, D., 1998b: Anti-homeless laws and public space II. Further constitutional issues. Urban Geography 19(1), 98-104.

Moore, S. F., 1973: Law and Social Change: The Semi-Autonomous Social Field as an Appropriate Subject of Study. Law \& Society Review 7 (4), 719-746.

Morrison, T.H., 2006: Pursuing rural sustainability at the regional level: key lessons from the literature on institutions, integration and the environment. Journal of Planning Literature $21,143-152$.

Murdoch, J. 1997: Towards a geography of heterogeneous associations. Progress in Human Geography, 21, 321-37.

Murdoch, J., 1998: The spaces of actor-network theory. Geoforum 29(4), 357-374.

Musselwhite, G. and Herath, G., 2005: Australia's regional forest agreement process: analysis of the potential and problems. Forest Policy and Economics 7, 579- 588.

Nash, C., 2000: Performativity in practice: some recent work in cultural geography, Progress in Human Geography 24, 653-664.

Norton, B. G., 2000: Biodiversity and environmental values: in search of a universal earth ethic. Biodiversity and Conservation 9(8), 1029-1044. 
Ostrom, E., 1995: Designing complexity to govern complexity. In Hanna, S. and Munasinghe, M. (eds) Property rights and the environment: social and ecological issues. The Beijer International Institute of Ecological Economics and the World Bank, Washington, DC, $33-46$.

Ostrom, E., 2005: Understanding Institutional Diversity. Princeton University Press.

Palmer, L., 2007: Interpreting 'nature': the politics of engaging with Kakadu as an Aboriginal place. Cultural Geography 14(2), 255-272.

Philippopoulos-Mihalopoulos, A., 2011a: Law's spatial turn: geography, justice and a certain fear of space. Law, culture and the humanities 7(2): 187-202.

Philippopoulos-Mihalopoulos, A., 2011b: Critical autopoiesis: the environment of the law. In De Vries, U. and Francot, L., (eds.) Law's Environment: Critical legal perspectives. Eleven international publishing, The Hague, 45-62.

Platt, R.H., 1996/2004: Land Use and Society: Geography, Law, and Public Policy. 1st/2nd editions, Island Press, Washington.

Popke, J., 2009: Geography and ethics: non-representational encounters, collective responsibility and economic difference. Progress in Human Geography 33(1), 81-90.

Porter, L., 2010: Unlearning the Colonial Cultures of Planning, Ashgate, Aldershot.

Posner, R. A., 1987: The Decline of Law as an Autonomous Discipline. Harvard Law Review 100(4), 761-780.

Prior, J.H., Boydell, S. and Hubbard, P. 2012: Nocturnal rights to the city: Property, propriety and sex premises in Inner Sydney, Urban Studies 49(8): 1837-1852

Prior, J.H. and Crofts, P., 2011: Queerying urban governance: the emergence of sex industry premises into the planned city. In Doan, P. (eds), Queerying Planning: Challenging heteronormative assumptions and reframing planning practice, New York, Ashgate Publishing Ltd, 185-208.

Prior, J.H., 2008: Planning for Sex in the City: urban governance, planning and the placement of sex industry premises in inner Sydney, Australian Geographer 39(3): 339-352 
Robinson, D., 2010: Locating Biopiracy: Geographically and Culturally Situated Knowledges. Environment and Planning A 42(1), 38-56.

Robinson, D. and Gibson, C., 2011: Governing Knowledge: Discourses and Tactics of the European Union in Trade-Related Intellectual Property Negotiations. Antipode: a radical Journal of Geography 43(5), 1883-1910.

Rodman, M.C., 1992: Empowering place: multilocality and multivocality. American Anthropologist 94 (3), 640-656.

Santos, B.D.S., 1995: Toward a New Common Sense: Law, Science and Politics in The Paradigmatic Transition. Routledge, New York and London.

Santos, B.D.S., 2002: Toward a New Legal Common Sense: Law, Globalization, and Emancipation. Butterworths, London.

Sassen, S., 2001: Spatialities and Temporalities of the Global: Elements for a Theorization. In Appadurai, A. (ed) Globalization, Duke University Press, Durham NC, 260-278.

Scott, C., 2003: Regulation in the Age of Governance: The rise of the (post-) regulatory state, Technical Report NEC Paper No 100, National Europe Centre, ANU.

Sherval, M., 2009: Native Alaskan engagement with social constructions of rurality. Journal of Rural Studies, 425-434.

Sluyter, A., 2003: Neo-environmental determinism, intellectual damage control, and nature/society science. Antipode 35 (4), 81-817.

Smith, N., 2001: Marxism and Geography in the Anglophone World. Geographische Revue 2, $5-21$.

Stanner, W. E. H. 1968/2009: The Boyer Lectures: After the Dreaming. In W.E.H. Stanner, The Dreaming and Other Essays (with an introduction by Robert Manne). Black Inc Agenda, Melbourne, 172-224.

Stratford, E., 1993. Ideology, Environment and Legislation: South Australian attitudes to native vegetation. Australian Geographical Studies 31(1), 14-25. 
Strathern, M., 1999: Property Substance and Effect: Anthopological Essays on Persons and Things. Athlone press, London.

Strelein, L. M. Dodson, M. and Weir, J., 2001: Understanding non-discrimination: native title law and policy in a human rights context. Balayi: Culture, Law and Colinialism 3, 113148.

Syvitski, J., 2012: Anthropocene: an epoch of our making. Global Change 78 (March), 12-15.

Tarlock, D., 2000: Putting rivers back in the landscape: the revival of watershed management in the US. Hastings West-Northwest Journal of Environmental Law and Policy 6 (2), $167-$ 198.

Tarlock, D. A., 2010: Environmental Law: Then and Now. Washington University Journal of Law and Policy 32(1), 1-31.

Valverde, M. 2009: Laws of the street. City and Society 21(2), 163-183.

Wainright, J., Prudham,S. and Glassman, J., 2000: The Battle in Seattle: Microgeographies of Resistance and the Challenge of Building Alternative Futures. Environment and Planning D 18(1), 5-13.

Wallerstein, I., 2010: Structural Crises. New Left Review 62, 133-142.

Warf, B. and Arias, S., 2008: Introduction: the reinsertion of space in the humanities and social sciences. In Warf, B. and Arias, S. (eds) The Spatial Turn: Interdisciplinary perspectives. Routledge, New York and London, 1-10.

Webber, M., 1994: Markets, resources, environments. Australian Geographical Studies 32(1): 3-16.

Weber, C. 1998: Performative states. Millennium -Journal of International Studies 27, 77-97.

Weber, E., 2000: A new vanguard for the environment: grass-roots ecosystem management as a new environmental movement. Society and Natural Resources 13 (3), 237-259.

Weir, J. K. 2009: Murray River Country: an ecological dialogue with traditional owners. Aboriginal Studies Press, Canberra. 
Weller, S., 2007: Power and scale: the shifting geography of industrial relations law in Australia. Antipode 39(5), 896-919.

Whatmore, S., 2002a: De/re-territorializing possession: the shifting spaces of property rights. In Holder, J. and Harrison, C. (eds) Law and Geography. Oxford University Press, Oxford, 211-223.

Whatmore, S., 2002b: Hybrid Geographies: Natures, cultures, spaces. Sage, London.

Whatmore, S., 2003: De/re-territorializing possession: the shifting spaces of property rights. In Holder, J. and Harrison, C. (eds) Law and Geography. Oxford University Press, Oxford, 211-23.

Whatmore, S., 2006: Materialist returns: practicing cultural geography in and for a more-thanhuman world. Cultural Geographies 13, 600-609.

White, D., 2006: A political sociology of socionatures: revisionist manoeuvres in environmental sociology. Environmental Politics 15 (1), 59-77.

Williams, S., 2010: On islands, insularity and opium poppies: Australia's secret pharmacy. Environment and Planning D: Society and Space 28(2), 290-310.

Wilson, C., 1956. The Outsider, Gollancz, London.

Wright, S., Lloyd, K., Suchet-Pearson, S., Burarrwanga, L., Matalena Tofa, M and Bawaka Country, 2012: Telling stories in, through and with Country: engaging with Indigenous and more-than-human methodologies at Bawaka, NE Australia. Journal of Cultural Geography 29, 39-60.

Yeager, P. C., 1991: The Limits of Law: the public regulation of private pollution. Cambridge University Press, Cambridge.

Yiftachel, O., 2001: Introduction: Outlining the power of planning. In Yiftachel, O., Alexander, I., Hedgcock, D. and Little, J. (eds) The Power of Planning: spaces of control and transformation, Kluwer Academic Press, The Hague, 1-20. 